\section{UČITELJI V 19. STOLETJU V BOJU ZA SLOVENSKO IDENTITETO}

Vloga slovenskih učiteljev pri razvoju narodne identitete Slovencev $v$ drugi polovici 19. stoletja
Dr. Monika

GovekarOkoliš, Filozofska fakulteta Univerze $v$ Ljubljani

\title{
POVZETEK
}

Slovenski učitelji so imeli $v$ času druge polovice 19. stoletja veliko vlogo pri oblikovanju in razvijanju narodne identitete Slovencev. Njihova vloga je še toliko pomembnejša, ker so v omenjenem času živeli znotraj avstrijske države, v kateri smo bili Slovenci razdeljeni po posameznih deželah. Uradni jezik je bila nemščina, kar je veljalo za vse uradne institucije, tudi za šole, kjer so slovenski učitelji poučevali v nemščini. Izobraževanje učiteljev je na učiteljiččì prav tako potekalo v nemščini in vzgoja je bila vzgoja k pripadnosti avtrijski državi. To dejstvo nam kaže, da so takratna učiteljišc̆a, kjer so se šolali bodoči slovenski učitelji, vzgajala v nemškem in ne $v$ slovenskem duhu, kar je bilo v skladu s takratno avstrijsko šolsko politiko. Vendar je bila nacionalna zavest slovenskih učiteljev na visoki ravni. Njihov glavni cilj je bil poleg spoštovanja zahtev avstrijske šolske politike tudi širjenje slovenskega jezika, kulture in tiska. Slovenska nacionalna prizadevanja so bila $v$ šolah prepovedana, zato so jih širili pri svojem delovanju izven šol. Ustanavljali so svoja slovenska učiteljska društva, svoj tisk in s tem spodbujali k nacionalnemu in buditeljskemu delu. Skrbeli so za lastno izobraževanje in tudi za izobraževanje vsega slovenskega prebivalstva. Prizadevali so si za slovenske šole s slovenskim učnim jezikom, za slovenske učbenike in sploh za razvijanje nacionalne identitete Slovencev.

Ključne besede: slovenski učitelji v 2. polovici 19. stoletja, nacionalna identiteta Slovencev, nacionalna prizadevanja učiteljev, slovenska učiteljska društva, učiteljski tisk, izobraževanje učiteljev

P razvoju nacionalne identitete Slovencev so imeli $\mathrm{v}$ okviru šolstva še posebej tisti slovenski učitelji, ki so imeli razvito nacionalno zavest in so se res čutili Slovence. Vloga učiteljev pri oblikovanju nacionalne identitete Slovencev je bila $\vee$ drugi polovici 19. stoletja večplastna. Delovali so tako v šolah kot tudi zunaj njih, svojo vlogo pa so opravljali tudi s strokovnim delom. Med zavednimi učitelji je bila pomembna njihova povezanost $\mathrm{z}$ okoljem, $\mathrm{v}$ katerem so skrbeli za vzgojo in izobraževanje ter širjenje nacionalnih idej. $\mathrm{V}$ drugi polovici 19. stoletja se je začelo učiteljstvo dokončno osamosvajati od neposredne odvisnosti od Cerkve, kar se kaže $\mathrm{v}$ tem, da se nista več povezovali cerkovniška in učiteljska služba (Melik, 1970). Z liberalno šolsko zakonodajo, zlasti s 


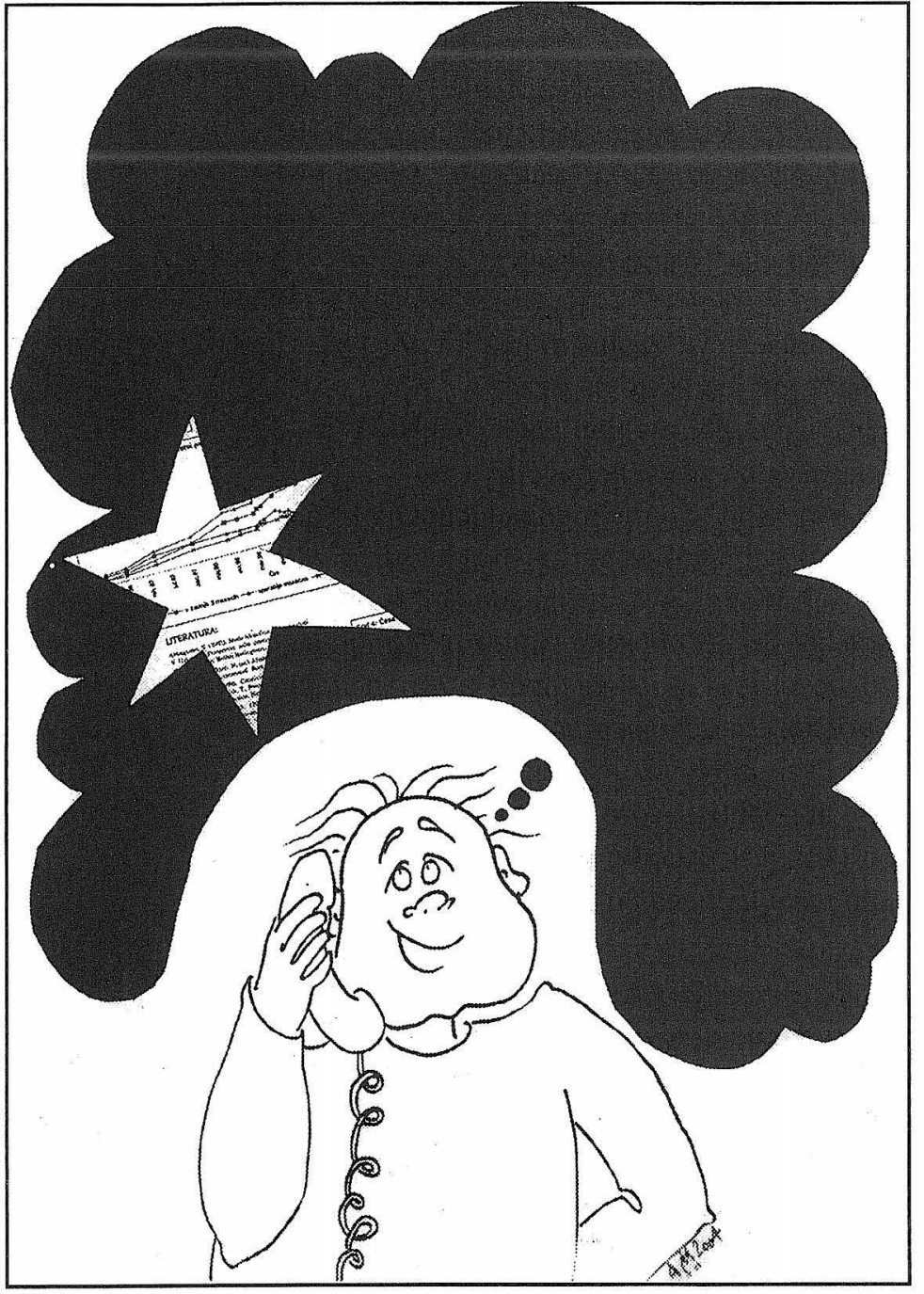

šolskim zakonom iz leta 1869 , je bil narejen dodaten korak v tej smeri. Izboljševal se je položaj učiteljev, saj so okrajne in deželne šolske oblasti skrbele za

Učiteljstvo se je začelo osamosvajati od Cerkve $v$ drugi polovici 19. stoletja. njihove dohodke, poleg tega pa so se izboljšali materialni pogoji šolstva, ki so tudi učiteljem omogočili, da so lahko ekonomsko in kulturno bolj napredovali (Schmidt, 1988). Učitelji so dobili boljšo možnost pridobivanja učiteljske izobrazbe, saj so se namesto na dotakratnih dveletnih tečajih (uvedenih $\mathrm{v}$ šolskem letu
1849/50) izobraževali na štiriletnih strokovnih šolah - učiteljiščih (ib.). V tem času se učiteljiščem pripisuje germanizatorska vloga. Zato iz njih ni moglo neposredno izvirati navduševanje novih učiteljev nad buditeljskim delom. Prav to nasprotje med šolskim poukom in zunanjim nacionalnim vrenjem pa je v marsikaterem mladem učitelju prebudilo nacionalno zavest. Le zavedni slovenski učitelji so bili lahko med poukom in pri delu na šolah sploh aktivni nosilci slovenske narodnostne vzgoje in vseh narodnostnih zamisli. Vse to so lahko širili in razvijali tako pri gojencih $\mathrm{v}$ slovenskem jeziku kot tudi prek vsebine pouka pri nacionalni skupini predmetov.

\section{POLOŽAJ SLOVENSKIH UČITELJEV $\checkmark$ ŠOLAH IN NJIHOVO NACIONALNO DELOVANJE}

Položaj, ki so ga imeli zavedni slovenski učitelji po nekaterih slovenskih pokrajinah v drugi polovici 19. stoletja na šolah, ni bil lahek niti povsod enak. Učni jezik je bil nemški, učitelji pa so odgovarjali avstrijski šolski oblasti in njenim šolskim nadzornikom. V šolah so delali med učitelji nemške, ponekod pa tudi italijanske in madžarske narodnosti. Morali so spoštovati šolski red in disciplino, ki jo je z zakonodajo predpisovala avstrijska šolska oblast.

Zaradi primerov, ko so šole na Slovenskem zavračale nemški jezik kot učni jezik, je začela avstrijska šolska oblast skrbneje nadzorovati delo šol. Zabeležila je, da je po šolah na Slovenskem vedno manj nemškega pouka, da se je uspeh tega slabšal, vzrok pa je našla v vse večjem poudarjanju nacionalnosti, nacionalnih usmeritev v slovenskih deželah (Deželna vlada ..., 1865). Zato so učitelje sprva le svarili, naj ne opuščajo nemške literature zaradi nacionalnosti in naj še naprej poučujejo v nemškem jeziku. Avstrijske šol- 
Učiteljsko nacionalno delovanje na šolah se je usmerjalo v razvijanje slovenske nacionalne zavesti in identitete ter je kmalu začelo motiti predvsem najbolj germanizatorsko usmerjene predstavnike šolskih oblasti (deželnih, okrajnih in krajevnih svetov) ter tako usmerjenih učiteljev po šolah. Kot primer naj omenimo, da je kranjska deželna vlada že leta 1869 vse okrajne glavarje $v$ deželi opozarjala, da učitelji izrabljajo šolo za politično nacionalno agitacijo in si pri tem dovoljujejo izjave, ki navajajo mladino $\mathrm{k}$ sovraštvu do drugih narodnosti (Deželna vlada ..., 1869), zato so glavarji z vsemi sredstvi skrbno nadzorovali ravnanje učiteljev in jim preprečevali njihovo nacionalno vzgojo (Deželna vlada ..., 1869). Takratna šolska uprava je v svoji strukturi imela vse možnosti nadzorovanja dela slovenskega učiteljstva. Osnovnošolski učitelji pa so svojo aktivno vlogo v narodnem boju zastopali tako, da so skupaj $z$ duhovšěino in dekanom $v$ šolah začeli poučevati samo $v$ slovenščini (Namestniški ..., 1854), s čimer so zapostavljali nemščino.

ske oblasti so grajale slovenske učitelje, češ da so zanemarjali nemški pouk predvsem po politično-nacionalni strani, da so se nagibali $\mathrm{k}$ napačnim novim nacionalnim smerem novega časa (ib.).

\section{IZVENŠOLSKA NACIONALNA DELOVANJA SLOVENSKIH UČITELIEV}

Še bolj so avstrijsko šolsko oblast motila različna izvenšolska nacionalna delovanja učiteljev. Slovenski učitelji so se konec šestdesetih in v sedemdesetih letih 19. stoletja udeleževali taborov, ki so bili po Slovenskem vse množičnejši. Nekateri med njimi, denimo Raič, je na ormoškem taboru 8. avgusta 1869 govoril o vzgoji slovenske mladine, ki naj bi bila marljiva in delovna ter $\mathrm{v}$ korist svojemu narodu, poštena in pravična, da se bo upirala tujemu in krivičnemu gospodarstvu nad slovenskim narodom in bo iskreno ljubila svoj dom in rod. V svojem govoru pa je Raič poudaril tudi pomen ustanovitve Zedinjene Slovenije, saj je menil, da je ta edina rešitev za Slovence (Raič, 1869). Tako so tudi učitelji začeli s politično-nacionalnim delovanjem in so se zavzemali za Zedinjeno Slovenijo. Nasplošno pa se je zavedno slovensko učiteljstvo zavzemalo za širitev šolske mreže na Slovenskem, za šolstvo (od osnovne šole do univerze), ki naj bi potekalo v slovenskem učnem jeziku, za slovenske šolske knjige in drugo literaturo ter za izboljšanje lastnega položaja.

Proti takemu ravnanju učiteljstva je avstrijska šolska oblast izdala nekaj določil, naprimer, da je potrebno z vso strogostjo nastopiti proti nevarni strasti osnovnošolskega učiteljstva do politično-nacionalnega delovanja in usmeriti vso pozornost $\mathrm{v}$ to, da bodo živeli učitelji izključno za svoj poklic. Določala je tudi, da se po potrebi lahko z neizprosnimi odpustitvami učiteljev iz službe postavi svarilen zgled. Pri tem je bilo tudi omenjeno, da vlada nikakor ne bo trpela učiteljev, ki zganjajo politiko in tako škodijo šoli, namesto da bi se izpopolnjevali $\mathrm{v}$ svoji stroki (Deželna vlada ..., 1866). Tudi Schmidt (1988) omenja, da se je na Kranjskem začela politična gonja proti narodno zavednim učiteljem. Kranjska deželna vlada je opozarjala učitelje s posebno okrožnico, naj se ne uveljavljajo na področjih, ki niso združljiva z njihovim službenim položajem. Taka opozorila so krožila leta 1867 , ko so bile volitve $v$ deželni zbor in so učitelji širili nacionalne zahteve. Deželna vlada je pogosto tudi kazensko premeščala učitelje iz enega kraja v drugega. Takšna društva so s svojimi

\section{Ucritelii so bili aktivni udeleženci taborov.}


akcijami lahko hitreje širila svojo asimilacijsko dejavnost. Tako se je ustanovilo društvo Schulverein, ki je skrbelo za germanizacijo, in društvo za italijansko asimilacijsko dejavnost na šolskem področju Pro patria.

Učitelji so bili boj za slovensko šolo.

Nemško društvo Schulverein je bilo ustanovljeno leta 1880 in je na področju Primorske, v Škednju, ustanovilo svojo zasebno šolo (Pahor, 1970), društvo Pro patria pa je bilo ustanovljeno 28. novembra 1886 v Roveretu na Trentinskem, delovalo pa je po vsej Primorski in tudi Dalmaciji. Cilj društva je bilo ustanavljanje italijanskih šol in vrtcev (ib.). Slovensko učiteljstvo se je moralo na Primorskem v sedemdesetih in osemdesetih letih 19. stoletja upirati vsem tem asimilacijskim pritiskom. Tako je bila na Primorskem poleg učiteljskih društev, kot navaja Vivante, najvplivnejša Družba sv. Cirila in Metoda, o kateri je zapisal: "Družba sv. Cirila in Metoda teži za tem, da razvije pri svojih učencih kulturo na izvirnih etničnih osnovah." (Vivante, 1945, str. 170). To družbo so ustanovili tudi v Gorici, z njo pa so se Goričani borili proti nemški in italijanski asimilaciji (Gabršček, 1932).

Poseben in še težji položaj ter vlogo so imeli zavedni slovenski učitelji na Koroškem, kjer

Šele $v 70$. letih 19. stoletja se začnejo (tudi) slovenski učitelji povezovati $v$ društva. jih je celo primanjkovalo. Kot omenja Ude, je bila na Koroškem večina učiteljstva proti pouku slovenščine tako na osnovnih kot tudi na srednjih šolah, in bi "le nacionalno pravično, strpno in vestno učiteljstvo moglo do neke meje preprečiti nujno škodljive posledice slovenstvu sovražnih učnih načrtov, nasprotovanj deželnega šolskega sveta in okrajnih šolskih svetov, pomanjkanja dobrih šolskih knjig." (Ude, 1970, str. 200). Večina učiteljstva na Koroškem je postala po letu 1869 "zagrizena nasprotnica
Še težji položaj in vlogo so imeli zavedni slovenski učitelji $\mathrm{v}$ obmejnih slovenskih krajih, predvsem na Primorskem in Koroškem. Tu so se morali spopadati z zahtevami zlitja slovenskega prebivalstva $\mathrm{v}$ prodirajoěa italijanski in nemški narod. Bili so boj za rešitev slovenske šole, da ne bi postala sredstvo asimilacije $v$ rokah italijanskih iredentistov in nemških germanizatorjev, ki so začeli zaradi počasnejšega razvoja demokratizacije in naraščajočega nacionalno-političnega delovanja, nacionalne zavesti in identitete Slovencev ustanavljati svoja šolska društva.

slovenskega pouka ... poslušno orodje liberalnih, nemško nacionalističnih oblastnikov." (ib., str. 201). Vzrok za to vidi Ude že v socialni sestavi koroškega vodstva (nemško usmerjenega), ki je imelo po kriteriju nemškega liberalizma po letu 1869 vse zahteve in prizadevanja za slovenski jezik in slovenske nacionalne pravice za "reakcionarne" zahteve (ib.). Večina koroških učiteljev pa se je žal oprijela tega pojmovanja. Šolska politika koroških oblastnikov si je tudi v nadaljnjih desetletjih vztrajno prizadevala, da je na utrakvistične šole zaposlovala le tako učiteljstvo, ki "si je že s svojim obnašanjem na učiteljišču pridobilo njihovo zaupanje." (Ude, 1970, str. 201). To nam kaže, da je bilo po vsej verjetnosti zavednih slovenskih učiteljev na Koroškem malo, saj so bili kot manjšina med učiteljstvom prisiljeni popuščati v nacionalnih zahtevah, predvsem glede slovenskega pouka. Tako so se zavedni koroški slovenski učitelji, zaradi neuspelih prizadevanj za temeljno organizacijo slovenskega pouka na koroških šolah in pravno trdnejše učne načrte, $v$ nadaljnjih desetletjih preusmerili zgolj na zahteve po izvajanju določil učnega načrta za osnovne šole in na zahtevo po boljšem učiteljstvu, ki bi imelo 
dovolj strokovnih znanj (ib.). To je pomenilo, lahko sklepamo, da so se ti sčasoma oddaljevali od nacionalnih zahtev, še zlasti po uvedbi slovenščine v vse šole na Koroškem.

\section{POVEZOVANJE SLOVENSKIH UČITELIEV V UČITELJSKA DRUŠTVA}

Primerov, ki nam kažejo zavedno izvenšolsko delovanje učiteljstva po slovenskih deželah, je veliko. Nacionalno zavedni učitelji so delovali na taborih, poleg tega pa so se začeli prav $\mathrm{v}$ šestdesetih in sedemdesetih letih 19. stoletja - v času največjih germanizatorskih pritiskov - povezovati v učiteljska društva, ki so, sprva posamično, nastajala po vseh slovenskih deželah. Bilo jih je približno dvajset in so bila razdeljena na deželna učiteljska društva, okrajna in krajevna (Učiteljska in ..., 1873). Po podatkih, ki jih navaja Slovenski učitelj, so bila na Slovenskem leta 1873 naslednja učiteljska društva:

\section{Na Kranjskem (prva štiri v Ljubljani):}

1. Slovensko učiteljsko društvo,

2. Narodna šola,

3. Krainischer-Lehrerverein,

4. Schulpfennig-Verein,

5. Okrajno učiteljsko društvo v Černomlju,

6. Okrajno učiteljsko društvo v Radovljici,

7. Učiteljsko društvo okrajne šolske bukvarnice v Idriji,

8. Učiteljsko društvo okrajne učiteljske bukvarnice v Vipavi.

"Da bi bilo še več takih društev na

Kranjskem, nam ni znano." (Učiteljska in ..., 1873, str. 35).

\section{Na Štajerskem:}

9. Učiteljsko društvo v Mariboru,

10. Učiteljsko društvo v Celju,

11. Učiteljsko društvo na Ptuju,
Učiteljska društva so, kot pravi Schmidt, opravljala tri pomembne naloge. "Svoje člane so vzgajala $v$ 'narodnobuditeljskem' duhu in se potegovala za slovensko šolo, prizadevala so si za izboljšanje učiteljevega gmotnega položaja in z raznimi oblikami $-s$ prirejanjem pedagoških predavanj, posredovanjem pedagoške literature na dom, $\mathrm{z}$ organizacijo vzornih nastopov itd. - skrbela za nadaljnje strokovno izpopolnjevanje učiteljstva." (Schmidt, 1988, str. 241)

12. Okrajno učiteljsko društvo v Ljutomeru,

13. Društvo učiteljev in šolskih prijateljev

na Vranskem.

Poleg tega je omenjeno, da sta osnovani, oziroma se še ustanavljata učiteljski društvi v Slovenski Bistrici in Brežicah (ib.).

\section{Na Koroškem:}

14. Učiteljsko društvo za vso Koroško, 15. Učiteljska podružnica celovške okolice,

16. Učiteljsko društvo Spodnje Ziljske doline,

17. Učiteljska podružnica v Beljaku,

18. Učiteljska podružnica v Velikovcu.

Pri omenjenih društvih je pripisano: "Se ve, da $v$ teh društvih ne veje ravno slovenski duh!" (Učiteljska in ..., 1873, str. 35), kar podobno kaže tudi že omenjen položaj učiteljstva na Koroškem.

Omenjeni prispevek žal ne navaja, katera so bila društva na Primorskem. Omenja le, da "Po slovenskem Primorju nam niso znana učiteljska ali šolska društva. Morda jih ni ali se pa ne poroča (!) o njih." (Učiteljska in ..., 1873, str.

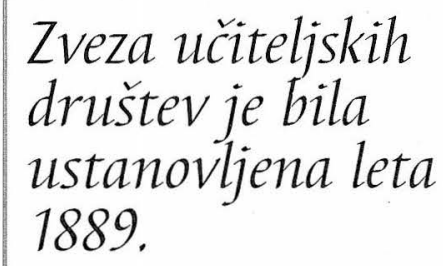

35). Seveda to ne pomeni, da na Primorskem ni bilo učiteljskih društev, saj Pahor omenja dve neslovenski društvi (Schulferein in Pro patrio). Kasneje nam v delovanju slovenskih učiteljskih društev razkrije podatek, da so se primorska učiteljska društva povezala $\mathrm{Z}$

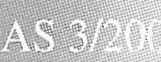




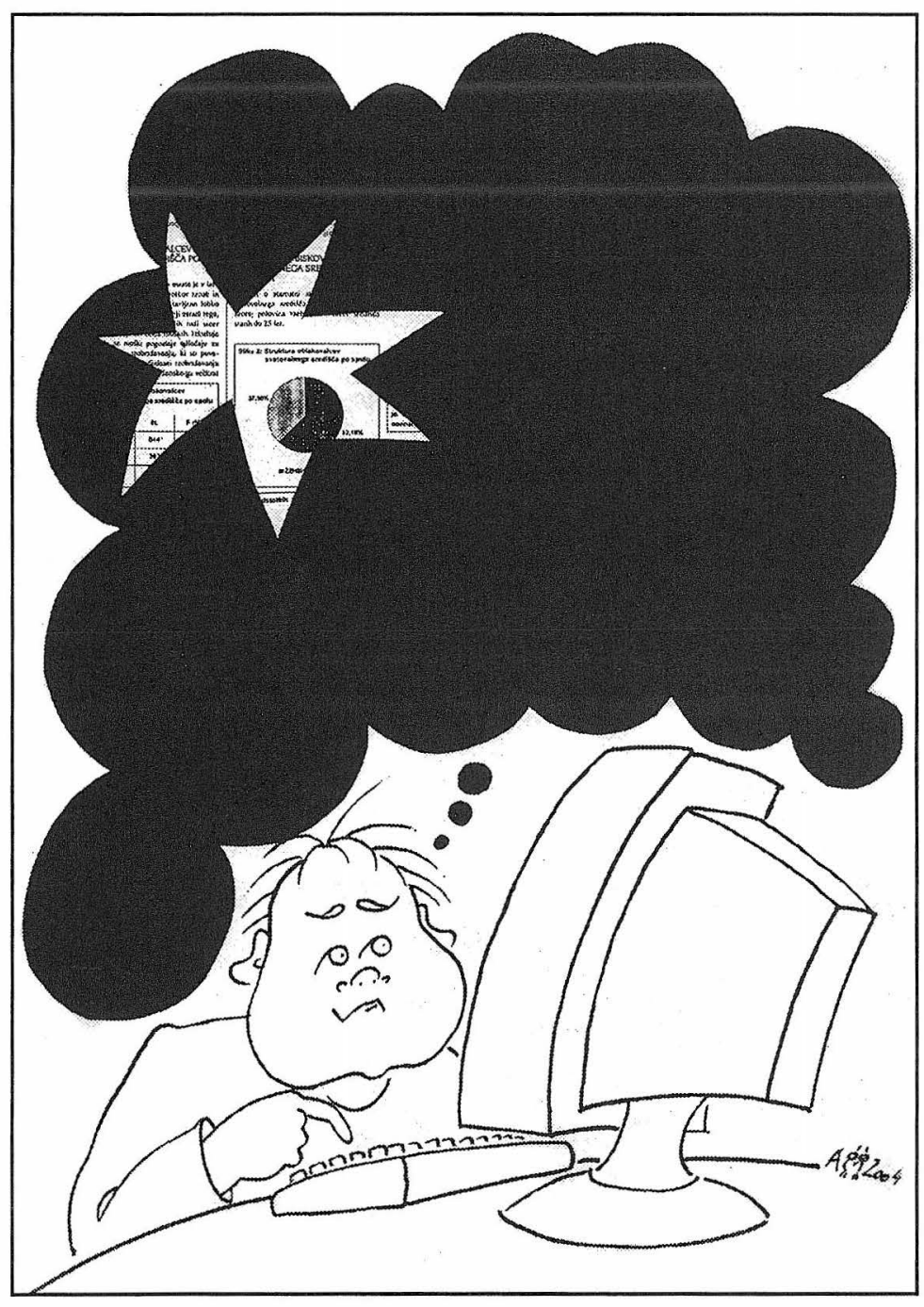

drugimi slovenskimi učiteljskimi društvi $\mathrm{v}$ enotno učiteljsko organizacijo - Zavezo slovenskih učiteljskih društev (Hojan, 1989). Žal imen teh društev nismo našli. Tako iz Učiteljskega tovariša tudi ni zaslediti števila učiteljskih društev posebej za Trst in širše področje, tj. Istro.

Med društvi omenimo najstarejšo učiteljsko ustanovo - Društvo za pomoč učiteljskim vdovam in sirotam, ustanovljeno leta 1860 (Hojan, 1989), ki je skrbelo predvsem za materialno pomoč učiteljem. Prvo pedagoško društvo, ki se je zavzemalo za izobraževanje ljudstva, napredek šolstva in boljše uspo- sabljanje učiteljev, $\mathrm{z}$ imenom Pedagoško društvo za učitelje in šolske prijatelje, pa je bilo ustanovljeno leta 1886 v Krškem (Strmčnik, 1986). Učiteljska društva so sprva delovala vsako zase, brez povezave. Nekatera med njimi, denimo na Štajerskem, so bila povezana $\mathrm{z}$ graškim društvom Lehrerbund. Vendar so v štajerskem Lehrerbundu zaradi nasilnejšega nemškega nacionalizma in razvijanja slovenske narodne zavesti nastajala številna nacionalna nasprotja med učiteljstvom, ki so povzročila $v$ letih od 1885 do 1887 izstop mariborskega, celjskega, ptujskega in ljutomerskega učiteljskega društva (Hojan, 1989).

Kranjsko učiteljsko društvo je leta 1872 razširilo svoje delovanje, tako da je privabilo tudi druge slovenske učitelje. Istega leta se je preimenovalo v Slovensko učiteljsko društvo, ki je ukinilo lokalna učiteljska društva. Leta 1887 je Celjsko učiteljsko društvo priredilo zborovanje, na katerem je predaval učitelj Kocbek. Poudarjal je pomen ustanovitve skupne učiteljske organizacije, ki bi združevala vsa slovenska učiteljska društva. Kocbekov koncept so zavedni slovenski učitelji sprejeli in hkrati sestavili svoj odbor učiteljev, ki je skrbel za ustanovitev organizacije. Člani so bili: Kocbek, podučitelj iz Žalca, Gradišnik, podučitelj iz Hrastnika, in Brezovnik, učitelj iz Vojnika (Hojan, 1989). Že v letu 1888 je bilo vse pripravljeno za ustanovitev organizacije, vendar je avstrijska oblast z vso silo ovirala to aktivnost naših učiteljev, ker je $\mathrm{v}$ Zvezi učiteljev videla panslavistično ustanovo (ib.).

Zveza učiteljskih društev v Ljubljani je bila dokončno ustanovljena 22. aprila 1889. Imenovala se je Zaveza slovenskih učiteljskih društev, ki je ob ustanovitvi štela že 18 učiteljskih društev, in sicer deset na Štajerskem in po štiri na Kranjskem in Primorskem (Hojan, 1989). Ob tej priložnosti je Učiteljski tovariš $\mathrm{v}$ prispevku $\mathrm{z}$ naslovom "Učitelj slovenski gre na dan" opisal navdušenje 
slovenskih učiteljev nad ustanovitvijo "Zaveze ...". Med drugim je bilo zapisano: "Ako nas ne varajo vsa znamenja, smemo učitelji slovenski zaupno zreti v tekočega leta dobo. Tolikanj zaželjena Zaveza slovenskih učiteljskih društev je osnovana; ponosno lehko kaže vesoljno učiteljstvo slovensko na svojega resnega hotenja učinek - kajti ravno pri osnovi Zaveze pokazali so učitelji slovenski razumništvu svojemu ter tudi onim svojim sodrugom, da vedo dostojno ceniti stanovski svoj poklic in da so si v svesti imenitnosti, ki jo zavzema dandanes tesna zdruŽitev." (Učitelj slovenski ..., 1889, str. 65).

Sprva so se učitelji povezovali $v$ organizacijo ne glede na svetovni nazor, kasneje pa so med njimi nastala trenja zaradi vse večjega vpliva političnih strank. Leta 1899 so učitelji katoliškega svetovnega nazora ustanovili svojo lastno učiteljsko organizacijo $\mathrm{z}$ imenom Slomškova zveza (Hojan, 1990). Tako bi lahko na splošno menili, da je "Zaveza ..." najprej izhajala iz političnega programa Zedinjene Slovenije, saj je pomenila strokovno organizacijo, ki naj bi povezala slovensko misleče učitelje na celotnem slovenskem ozemlju, podobno kot so bile zamisli po povezanosti vseh slovenskih dežel $\mathrm{v}$ eno, Zedinjeno Slovenijo.

Zanimivost te organizacije je tudi, da je bilo njeno delo razdeljeno na posamezne odseke. Leta 1892 je bil ustanovljen Slomškov odsek, ki je skrbel za izdajo Slomškovih zbranih spisov za mladino - pomembnega prispevka k slovenski mladinski literaturi. Poleg tega je bil istega leta ustanovljen Vrtnarski odsek, ki je imel nalogo, da med učiteljstvom pospešuje zanimanje za vrtnarstvo. Odsek za učila, prav tako ustanovljen leta 1892, je znan po tem, da je že v naslednjem letu pripravil razstavo učil v Mariboru, ki so jo oblikovali učitelji (ib.). Znotraj "Zaveze ..." je deloval tudi Odsek za ocenjevanje mladinskih knjig, ustanovljen leta 1893. Ta je ocenjeval slo-
Namen Zaveze slovenskih učiteljskih društev je bil zavzemanje za šolske in učiteljeve interese, med katerimi so bili tudi nacionalni interesi. Uěitelji znotraj te organizacije so zborovali enkrat letno, vedno v drugem kraju. $\mathrm{Na}$ vseh zborovanjih so potekala strokovna predavanja in poročila o delu šol v tekočem letu (Hojan, 1990), pri čemer so lahko poudarjali tudi nacionalne zahteve v šolstvu na Slovenskem.

venske mladinske knjige, ki so takrat izšle, in organiziral Knjižnico za mladino, ki jo je vodil Leban. Odsek se je povezoval tudi s prijateljem slovenskih učiteljev iz Prage, Legom, ki je podprl mladinsko književnost na Slovenskem s sredstvi za nagrado za najboljši mladinski spis, razpisovala pa ga je "Zaveza ..." (Hojan, 1990).

Te oblike delovanja učiteljev $\mathrm{v}$ odsekih "Zaveze ..." nam kažejo, da so učitelji skrbeli tako za svoj strokovni in kulturni razvoj kot tudi za tovrstni razvoj Slovencev nasploh. Znotraj vseh omenjenih njihovih delovanj in prizadevanj pa so širili tudi nacionalno zavest in identiteto slovenskega naroda, tako da so poudarjali vse slovensko, predvsem pa so skrbeli za izobraževanje in nacionalno vzgojo Slovencev tako v šolah kot tudi v širši družbi.

Zaveza slovenskih učiteljskih društev je skrbela za splošno izboljšanje šolstva na Slovenskem, saj je s svojim delovanjem med drugim tudi pospeševala pisanje slovenskih mladinskih spisov in knjig, še posebno s tem, da jih je nagrajevala. Zavzemala se je za uresničitev vseh šolskih in učiteljskih teženj in leta 1895 ustanovila podporno društvo za učitelje - Društvo za zgradbo učiteljskega konvikta, katerega idejni ustanovitelj je bil Dimnik. Zaveza slovenskih učiteljskih društev je leta 1898 na prvi mestni deški osnovni šoli v Ljubljani ustanovila tudi Šolski muzej, ki ga je vodil Dimnik (Hojan, 1990), posebej je skrbela tudi za pedagoške knjige, revije in tisk. Za svoje glasilo je izbrala pedagoški list Popotnik, leta 1900 pa je prevzela tudi Učiteljskega tovariša (ib.).

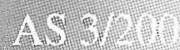

A. 6 ( ) 


\section{POMEN UČITELJSKEGA TISKA, ŠOLSKIH KNJIŽNIC IN UČITELJSKIH KONFERENC}

Učitelji se niso neformalno izobraževali, izpopolnjevali in širili nacionalnih zamisli le prek društev, temveč tudi prek tiska, svojih knjižnic in $\mathrm{z}$ učiteljskimi konferencami. S

Strokovna učiteljska glasila kot element širjenja nacionalne zavesti.

tem so hitro pridobivali strokovna znanja, naraščala je njihova samozavest in nacionalna identiteta ter nadaljnje želje po izboljšanju šolstva na Slovenskem (Kedaj bode bolji, 1869).

Za učitelje v drugi polovici 19. stoletja so bila pomembna tudi strokovna glasila, saj so preko vanje vključene nacionalne tematike učitelji lahko oblikovali nacionalno identiteto Slovencev, zlasti med učitelji. Med prvimi strokovnimi glasili je bil Učiteljski tovariš, najstarejši učiteljski list, ki je začel izhajati leta 1861 pod uredništvom učitelja in pedagoškega pisatelja Praprotnika (Hojan, 1989). Ta učiteljski list je objavljal različne članke slovenskih učiteljev, pisateljev,
Lastnik lista je bil Nerat, ki je bil hkrati tudi urednik in upravnik. pesnikov in strokovnjakov, s katerimi so učitelji želeli dvigniti kakovost pouka. V njem so objavljali številne metodične članke in objave o "umnejšem" gospodarjenju, povzetke zahtev $\mathrm{z}$ različnih učiteljskih zborovanj, kjer so bile zapisane nacionalne težnje, objave o različnih razstavah in drugo. Učiteljski tovariš je za mnoge učitelje pomenil vir iskanja novih znanj ter metod in opisov določenih učnih izkušenj (Tomšič, 1970).

Učiteljskemu tovarišu zato lahko pripišemo velik pomen. Iz njegovih vsebin lahko razberemo, da se je ta zavzemal za šole s slovenskim učnim jezikom, in kot je zabeležil sam urednik Praprotnik, je ta časopis "prvi budil slovenske učitelje in jim kazal domačo
S pomočjo učiteljskih listov so si učitelji prizadevali dvigniti kakovost znanja $\mathrm{v}$ vseh šolah na Slovenskem. Želeli so šole v slovenskem jeziku, s slovenskimi učbeniki in knjigami (Pašnik, 1862), s čimer so omogočili tudi razvoj nacionalne identitete Slovencev.

pedagogiko." (Vabilo za ..., 1872, str. 353).

Poleg Učiteljskega tovariša je bil pomemben tudi list Popotnik, ki je bil namenjen za šolo in dom.

List je s svojimi vsebinami služil učiteljem, šolam in tudi staršem, zato je imel pomembno povezovalno vlogo med šolo in starši. Objavljal je članke, ki so po svoji vsebini prinašali tudi nacionalno tematiko. Na splošno, če povzamemo osnovne misli teh člankov, so ti omogočali razvoj in utrditev nacionalne vzgoje, tako da se je poudarjal pomen ljubezni do slovenskega jezika in naroda (Gradišnik, Materinščina, 1880), pomen prebiranja slovenske literature (Brezovnik, O knjižnicah za šolsko mladino, 1880), ohranjanja in petja slovenskih pesmi (Valentinič, Petje v ljudski šoli, 1881), za kar naj bi skrbeli učitelji $\mathrm{v}$ šolah ter starši in skrbniki po domovih (ib.).

Omenimo še pedagoški časopis Slovenski učitelj, ki ga je začel izdajati Lapajne, upravitelj Osnovne šole v Ljutomeru. Časopis je bil tiskan $\vee$ Mariboru in je izhajal od leta 1872 do leta 1877. Nastal je na pobudo liberalno usmerjenih učiteljev, ki so poleg Učiteljskega tovariša želeli imeti nov slovenski šolski list, ki bo zagovarjal novi šolski zakon iz leta 1869 (Ostanek, 1971). Slovenski učitelj je $\mathrm{v}$ svojih člankih, poročilih in razpravah zajemal vsebine $z$ vsega šolskega področja, predvsem pa je zagovarjal pomembnost šol s slovenskim učnim jezikom na Slovenskem. Tako je tudi Lapajne $v$ prvi številki Slovenskega učitelja objavil sestavek 
Naš program, v katerem je poudaril: "Da bodemo Slovenci v omiki vedno bolj napredovali, se nam je treba zlasti tudi za narodno šolstvo posebej zanimati. Treba je slovenske učitelje in odgojitelje napeljevati $\mathrm{k}$ večji strokovni omiki $v$ narodnem jeziku, narodnem duhu in narodnem smislu, treba je naše slovensko občinstvo ogreti za slovensko narodno šolo in naše domoljube prestvariti v prave šolske prijatelje." (Lapajne, 1872, str. 1).

$\mathrm{V}$ tem sestavku je Lapajne tudi izrazil svojo željo, da bi bil list politično neodvisen, in povedal, da bo zastopal koristi slovenske narodne oziroma osnovne šole ter se boril za pravice slovenskih učiteljev. V časopisu smo našli tudi članke, ki so opisovali kranjsko šolstvo, češ da to ni imelo dovolj zavednih in nepristranskih učiteljev ter šolnikov (Sedanje kranjske šolske razmere, 1875), pri čemer so se omenjali nasprotniki nove šolske reforme, ki so ovirali napredek šol na Slovenskem (Ali bo kranjsko šolstvo napredovalo?, 1875). Opozarjalo se je tudi na ponemčevanje (Nemščina po naših šolah, 1874), zasledimo pa tudi veliko zavzemanj za slovenščino kot učni jezik v vseh šolah (Uradni jezik naših narodnih šol, 1875). Poleg tovrstnih vsebin je list objavljal poročila o zborovanjih učiteljskih društev (Letošnje učiteljsko zborovanje na Primorskem, 1875), pisal tudi o preganjanju učiteljev zaradi nacionalnih vprašanj (Slovenski učitelji pod policajskim nadzorstvom, 1875), o stanju šol (O goriškem

S strokovnimi glasili so si slovenski učitelji lahko poglabljali strokovna znanja, hkrati pa krepili nacionalno zavest in nacionalno identiteto Slovencev. Poleg zgoraj omenjenih pedagoških strokovnih časopisov smo imeli na Slovenskem tudi nemško učiteljstvo, ki je osnovalo svoje strokovne časnike, katerih vsebine so nasprotovale slovenskim strokovnim časopisom. učiteljišči, 1875) in delovanju učiteljstva $\mathrm{v}$ strokovnih društvih (Vabilo $\mathrm{k}$ pervemu občnemu zboru Učiteljskega društva za slovenski Štajer, 1874).

Naj le omenimo, da je v Ljubljani izhajal Laibacher Schulzeitung, ki je bil še posebno nasprotujoč Učiteljskemu tovarišu. Laibacher Schulzeitung je bil v strokovno-pedagoškem pogledu zelo dober časopis, kot omenja Ostanek, vendar je bil nemško nacionalno usmerjen, saj je zagovarjal nemški učni jezik v šolah in utrakvistične šole na Sloven-
So bili lahko učiteljski listi politično neodvisni? skem (Ostanek, 1971). Primer nemškega pedagoškega časopisa nam razkriva, da je bilo delo slovenskih učiteljev še toliko težje zaradi nacionalno idejnih nasprotij nemških učiteljev, hkrati pa jim je to pomenilo tudi izziv za večja nacionalna prizadevanja, za širitev teh med slovensko učiteljstvo in tudi drugo slovensko prebivalstvo.

Odlok Ministrstva z dne 15. decembra 1871, ki je predpisoval dodatno izobraževanje učiteljstva in poudaril potrebo po izpopolnjevanju učiteljstva s pedagoškim tiskom in $\mathrm{z}$ ustanavljanjem okrajnih šolskih knjižnic, nadaljevalnih tečajev in periodičnih konferenc (Verordnungsblatt für ..., 1871), je pri slovenskih učiteljih spodbudil strokovno izpopolnjevanje znanj predvsem s pedagoškimi revijami ter drugim pedagoškim tiskom. V šestdesetih letih so na osnovi tega dobile pomembno vlogo tudi učiteljske okrajne "bukvarnice" - knjižnice, ki so se hitro širile po Leta 1871 je država predpisala dodatno izobraževanje učiteljstva.
Slovenskem - na Štajerskem, v Idriji, Postojni, Vipavi ... (Schmidt, 1988). Izpopolnjevanje znanja in širjenje slovenske literature s pomočjo "bukvarnic" sta pri učiteljih oblikovala še večjo zavzetost za dvig kakovosti slovenskih šol. O tem je pisal tudi 
Učiteljski tovariš: "Vsaka šola naj bi imela svojo knjižnico, če ne obširno, pa vsaj malo. Največ učiteljev je, ki nimajo tolike službe, da bi si mogli sami kupovati potrebnih knjig in časopisov za svoje izobraževanje in za oliko šolske mladine." (Vsaka šola naj ..., 1866, str. 199).

Omenjeni položaj učiteljstva, njihovega delovanja, izobraževanja in izpopolnjevanja nam kaže, kako so si učitelji lahko medsebojno izmenjavali znanje, izkušnje, hkrati

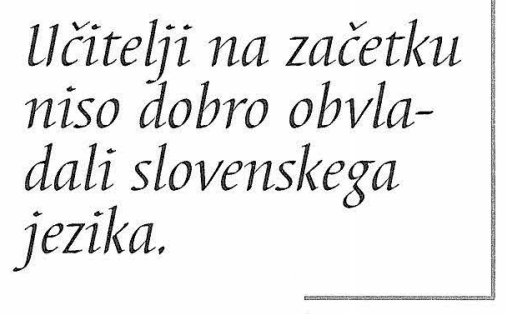

pa so pri vsem tem tudi razvijali nacionalno zavest in identiteto ne le prek svojih društev, pedagoškega tiska in učiteljskih knjižnic, temveč tudi prek učiteljskih konferenc. Te so sklicevala posamezna učiteljska društva, kamor so učitelji pošiljali svoje razprave, vezane na določeno šolsko problematiko. Vsa nacionalna obeležja učiteljev se kažejo v njihovih prizadevanjih za šole na Slovenskem, v katerih naj bi bil učni jezik slovenščina, za slovenske šolske knjige in drugo literaturo (Schmidt, 1988).

\section{IZOBRAŽEVANJE SLOVENSKIH UČITELJEV IN NJIHOVA NACIONALNO BUDITELJSKA VLOGA}

Osveščeni slovenski učitelji so se zavedali

Lavračev meni, da niso dovolj le znanja, ki jih razlagajo na učiteljiščih, tenveč si morajo slovenski učitelji po svojih najboljših močeh prizadevati za izobraževanje naroda ob vsaki priložnosti. Uěitelj mora ljubiti svoj narod in še posebej mladino. "Če je sploh znano, da učitelj ljubi narod in posebno mladino, da si prizadeva in jo izobražuje, ga tudi ljudje ljubijo in spoštujejo, in ne puste, da bi v materialni zadevi kaj terpel ... Vsak pravi učitelj pa, kteremu je sreěa in blagor domovine pri sercu, si prizadeva po vsi moči, da podučuje mladino, kedarkoli mu je mogoče ..." (Lavračev, 1864, str. 341). potrebe po lastnem izpopolnjevanju pomanjkljivih znanj, ki so jih dobili na učiteljiščih, zlasti o slovenski deželi in slovenskem jeziku. Učitelji niso dovolj obvladali slovenskega jezika, da bi ga lahko naprej razvijali in utrjevali. To je bilo sprva delo posameznikov, nacionalno zavednih in zavzetih učiteljev, ki so med učiteljstvom uspeli širiti nacionalne zamisli (Strmčnik, 1970). Na vseh slovenskih učiteljiščih je bil učni jezik nemški ali pretežno nemški, kar je seveda imelo nadvse zaviralen vpliv na naše učiteljstvo. Razvoj slovenskega jezika, slovenske kulture in nacionalne zavesti je bil oviran, hkrati pa je bila tudi otežena možnost oblikovanja nacionalne identitete slovenskega naroda in urejanja šol s slovenskim učnim jezikom, slovenskimi knjigami in z ustreznimi slovenskimi učitelji, ki bi skrbeli tudi za nacionalno vzgojo. O tem je Lavračev $v$ Učiteljskem tovarišu takole pisal: "Kedar bomo učitelji napredovali s duhom časa in se v svojem poslu izverstni kazali, takrat bo posijalo gorkeje solnce našemu milemu narodu. Da je naš narod še na bolj nizki stopnji omike, so krivi nekoliko učitelji, nekoliko pa poptujčene šole, v katerih se hoče narodu ptuja olika in kultura $v$ serce sejati; prezreti pa tudi ne moremo, da je še veliko občin, ktere $\mathrm{k}$ svoji oliki le trohice pripomoči nočejo." (Lavračev, 1864, str. 339). Poudaril je, da mora slovenski učitelj nujno napredovati (ib.).

Če so se slovenski učitelji zavedali tega, kar je pisal Lavračev, so lahko uresničevali svojo nacionalno buditeljsko vlogo tudi $\mathrm{v}$ širšem okolju, kjer so živeli in delovali. Kako in na kakšen način? Skrbeli za širjenje branj slovenskih knjig, časopisov in revij. Svoje učence so usmerjali tako, da so ti tudi doma radi prebirali poučne knjige in tako napredovali v svojem znanju. "Vsakemu mlademu sercu naj se vcepi ljubezen do dobrih bukev; dobre bukve v rokah mladega človeka so kaj lepo in priporočivno znamenje. Naj torej 
učitelji po deželi pogosto priporočajo svojim učencem družbo sv. Mohora v Celovcu, ki ima imenitni namen, da izdaja dobre in koristne bukve prav dober kup in jih razširja med slovenskim ljudstvom." (Narodni učitelj, 1865, str. 130). Pa ne le to. Ponekod so marljivi učitelji pripravljali "knjižnico slovenskih gospodarskih in sploh podučnih knjig, kakor tudi domačih časnikov, ktere ukaželjnim ljudem posojajo in brati priporočajo. Če jim pa ni moč si take knjižnice napraviti, si izposodijo knjige in časnike pri verlih omikanih ljudoljubih, kterih se nam, hvala Bogu! ne manjka; jih potem o priložnih časih kmečkim gospodarjem in znancom berejo in razkladajo, premožnejšim pa svetujejo in priporočajo, da bi se tudi pridružili slovenskim čitavnicam in drugim takim koristnim družbam." (Pašnik, 1862, str. 8) Učitelji so spodbujali neformalno izobraževanje slovenskih otrok, mladine in odraslih, tako da so jih učili slovenščino brati in pisati tudi zunaj šol.

Prav s tem, kot nam kaže opisani primer, so lahko učitelji dovolj uspešno širili znanje in hkrati tudi nacionalno identiteto med Slovenci. V kraju, kjer so delovali, so slovensko prebivalstvo prav vztrajno učili peti slovenske narodne pesmi, poleg tega pa tudi zbirali narodno blago. Kot nam kaže primer iz Učiteljskega tovariša, je učitelj Gerbic iz Trnovega napisal prošnjo vsem posameznikom, ki se ukvarjajo z glasbo in s petjem, naj mu pomagajo zbirati narodne pesmi in napeve, katere bo združil in oblikoval $\mathrm{v}$ zbirko narodnih pesmi (Gerbic, 1864). Poleg petja in zbiranja narodnega blaga so učitelji vedeli, da Slovenci potrebujejo "nauka $\mathrm{v}$ raznih vednostih: v kmetijstvu, sadjo-, sviloin bčeloreji in tudi v političnih zadevah." (Narodni učitelj, 1865, str. 131). Tako so se med Slovenci hitreje širila znanja, s tem pa tudi nacionalna pripadnost slovenskemu narodu. Učitelji so veliko -sodelovali tudi s starši otrok, ki so jih poučevali, saj so vedeli,

da je nujno potrebno skupno (nacionalno) vzgajanje in sodelovanje s starši, ki jim mora biti učitelj vedno za zgled. Tomšič je zapisal: "Šola in starši - starši in šola, podlaga so izobraževanja in sreča naroda!" (Tomšič, 1863, str. 195). Slovenski učitelji so imeli pomembno vlogo pri širjenju slovenske nacionalne

Učenje slovenskih narodnih pesmi in razvoj nacionalne identitete. identitete. Bili so akterji različnih prizadevanj za razvoj slovenske kulture, tiska, jezika ter pobudniki razvoja slovenske nacionalne zavesti in identitete.

\section{SKLEPNE MISLI}

$\mathrm{Na}$ osnovi navedenega o učiteljstvu na Slovenskem v drugi polovici 19. stoletja lahko vidimo, da prizadevanj zavednih slovenskih učiteljev za ohranjanje slovenskega naroda in za razvijanje nacionalne identitete pravzaprav ni bilo malo. To nam kaže njihovo delovanje tako $v$ šolah kot tudi izven njih. Izven šol so se priključevali ciljem širšega slovenskega prebivalstva, ki se je na taborih in $\mathrm{v}$ društvih navduševalo za nacionalne zamisli, med drugim segajoče tudi na šolsko področje. Ti učitelji pa so se, kot je videti, zavedali svoje vloge ne le $\mathrm{v}$ strokovnem izpopolnjevanju, povezovanju $\mathrm{v}$ učiteljska društva in $v$ "Zavezo ..." ter pri širjenju pedagoških časopisov in knjižnic, temveč tudi vloge ohranitve in razvijanja slovenske nacionalne vzgoje, s katero so lahko razvijali nacionalno zavest in identiteto tudi najbolj preprostemu Slovencu v šolah in izven njih. Slovensko učiteljstvo je imelo $\mathrm{v}$ svojem nacionalnem delovanju pomembno vlogo predvsem na šolah, saj so bili učitelji edini aktivni nosilci nacionalnih pobud, širjenja spoznanj o slovenskem narodu, njegovi kulturi, jeziku in zgodovini, s čimer so lahko vplivali na oblikovanje nacionalne zavesti in identitete. Zunaj šol pa so prispevali k širitvi 
slovenske pismenosti in razvoju slovenske kulture ter $\mathrm{s}$ tem širili nacionalno zavest in identiteto slovenskemu narodu. Njihova narodnobuditeljska vloga, nacionalna vzgoja v šlah in zunaj njih so bile zelo pomembne, saj so s svojimi prizadevanji in aktivnostmi uspeli razviti dovolj močno nacionalno identiteto Slovencev. Dokaz, da so slovenski učitelji v nacionalnih prizadevanjih uspeli, je vzpon slovenskega jezika na višjo družbeno in institucionalno raven, ohranitev slovenske kulture, razvoj slovenske znanosti in umetnosti ter vzpostavitev šolstva s slovenskim učnim jezikom. Vendar se to ni zgodilo tako hitro.

\section{LITERATURA}

Ali bo kranjsko šolstvo napredovalo? (1875). Slovenski učitelj, 20. februar, Maribor.

Brezovnik, T. (1880). O knjižnicah za šolsko mladino. Popotnik, 25. november, Celje.

Deželna vlada (1865). Fasc. 31 ad 9, št. 4749, 21. december. Ljubljana: Arhiv SRS. Državni arhiv Slovenije.

Deželna vlada (1866). Fasc. 31 ad 9, št. 4749, 18. april. Ljubljana: Arhiv SRS. Državni arhiv Slovenije.

Deželna vlada (1869). Fasc. 31 ad 9, št. 4357, 16. julij. Ljubljana: Arhiv SRS. Državni arhiv Slovenije.

Gabršček, A. (1932). Goriški Slovenci. I. knjiga. Ljubljana: samozaložba.

Gerbic, F. (1864). Prošnja. Učiteljski tovarišs, 1. marec, Ljubljana.

Gradišnik, A. (1880). Materinščina. Popotnik, 10. november, Celje.

Hojan, T. (1989). Ob stoletnici ustanovitve slovenske učiteljske organizacije. Ljubljana: Slovenski šolski muzej.

Hojan, T. (1990). Ob 100-letnici ustanovitve zveze slovenskih učiteljskih društev. Sodobna pedagogika, 3-4.

Kedaj bode bolji (1869). Učiteljski tovariš, 15. maj, Ljubljana.

Lapajne, I. (1872). Naš program. Slovenski učitelj, 1. december, Maribor.

Lavračev (1864). Kakšen naj bo učitelj, da ga narod spoštuje. Učiteljski tovariš, 15. november, str. 339-341.
Letošnje učiteljsko zborovanje na Primorskem (1875). Slovenski učitelj, 5. avgust, Maribor.

Melik, V. (1970). Slovenci in "nova šola". Osnovna šola na Slovenskem 1869-1969. Ljubljana: Slovenski šolski muzej.

Namestniški arhiv (1854). Fasc. 31 ad 18, št. 3760, 14. junij. Ljubljana: Arhiv SRS. Državni arhiv Slovenije.

Narodni učitelj (1865). Učiteljski tovariš, 1. maj, str. 130-131.

Nemščina po naših šolah (1874). Slovenski učitelj, 5. julij, Maribor.

O goriškem učiteljišču (1875). Slovenski učitelj, 5. maj, Maribor.

Ostanek, F. (1971). Ivan Lapajne in njegov pedagoški casopis Slovenski učitelj (1872-1877). Ljubljana: Slovenski šolski muzej.

Pahor, D. (1970). Pregled razvoja osnovnega šolstva na zahodnem robu slovenskega ozemlja. V Osnovna šola na Slovenskem 1869-1969. Ljubljana: Slovenski šolski muzej.

Pašnik (1862). Učiteljski tovariš, 1. januar, str. 8.

Raič, B. (1869). O izreji naše mladine. Slovenski narod, 14. avgust, Maribor.

Sedanje kranjske šolske razmere (1875). Slovenski učitelj, 20. junij, Maribor.

Schmidt, V. (1988). Zgodovina šolstva in pedagogike na Slovenskem. III. del. Ljubljana: Delavska enotnost.

Slovenski učitelji pod policajskim nadzorstvom (1875). Slovenski učitelj, 5. junij, Maribor.

Strmčnik, F. (1986). O pretečenem in nadaljnjem razvoju Zveze društev pedagoških delavcev Slovenije. Sodobna pedagogika, 9-10.

Strmčnik, F. (1970). Razvoj izobraževanja osnovnošolskega učiteljstva na Slovenskem v obdobju od leta 1869 do razpada Avstro-Ogrske. V Osnovna šola na Slovenskem 1869-1969. Ljubljana: Slovenski šolski muzej.

Tomšič, J. (1970). Oris osnovnošolskega prirodopisnega pouka na Slovenskem. V Osnovna šola na Slovenskem 1869-1969. Ljubljana: Slovenski šolski muzej.

Tomšič, L. (1863). Šola in starši. Učiteljski tovariš, 1. julij, str. 195

Učiteljska in šolska društva po Slovenskem (1873). Slovenski učitelj, 10. januar, str. 35.

Učitelj slovenski gre na dan! (1889). Učiteljski tovariš, 1. marec, str. 65 .

Ude, L. (1970). Zgodovina slovenskega pouka na koroških osnovnih šolah od leta 1869 do danes. V Osnovna šola na Slovenskem 1869-1969. Ljubljana: Slovenski šolski muzej, str. 200-201. 
Uradni jezik naših narodnih šol (1875). Slovenski učitelj, 5. april, Maribor.

Vabilo k pervemu občnemu zboru Učiteljskega društva za slovenski Štajer (1874). Slovenski učitelj, 20. avgust, Maribor.

Vabilo za naročbo "Tovariša" za prihodnje leto 1873 (1872). Učiteljski tovariš, 1. december, str. 353.

Valentinič, K. (1881). Petje v ljudski šoli. Popotnik, 10. oktober, Celje.

Verordnungsblatt für den Dienstbereich des Ministeriums für Cultus und Unterricht (1871). Dunaj: K.k. Staatsdruckerei.

Vivante, A. (1945). Irredentismo adriatico. Trieste."Italo Svevo", letnik XIII. Trst, str. 170.

Vsaka šola naj bi imela svojo knjižnico! (1866). Učiteljski tovariš, 1. julij, str: 199. 